\title{
CLAY MINERALOGY OF THE JURASSIC-TERTIARY SEDIMENTARY ROCKS OF THE KOPET DAGH BASIN (NORTHEASTERN IRAN): IMPLICATIONS FOR PALEOCLIMATE
}

\author{
Farhad KHORMALI $^{1{ }^{2}}$ * and Arash AMINI ${ }^{2)}$ \\ ${ }^{1)}$ Deptartment of Soil Sciences, Faculty of Water and Soil Engineering, Gorgan University of Agricultural Sciences \\ and Natural Resources, Gorgan, Iran \\ ${ }^{2)}$ Deptartment of Geology, Faculty of Sciences, Golestan University, Gorgan, Iran
}

*Corresponding author's e-mail: Khormali@yahoo.com

\section{ARTICLE INFO}

Article history

Received 9 February 2015

Accepted 3 July 2015

Available online 1 September 2015

Keywords:

Clay Minerals

Kopet Dagh Basin

Paleoclimate

Smectite

Palygorskite

\begin{abstract}
Distribution of the clay minerals in the Jurassic-Tertiary consolidated sediments of the Kopet Dagh Basin (KD) was investigated to study the origins of the clay minerals and to reconstruct the paleoclimate of the area. The entire sedimentary rock sequences of the KD were sampled for $\mathrm{XRD}, \mathrm{XRF}$, high resolution microscopy, and optical microscopy examinations. Illite, illitesmectite (IS) mixed-layer minerals, kaolinite, smectite, chlorite and palygorskite were found in the studied deposits. The presence of the clay minerals in the studied rocks was related partly to deep burial diagenesis and partly to the pedogenetic detrital origins. The thick sediments (total of $6000 \mathrm{~m}$ ) of the Lower Cretaceous and Jurassic suggest the possibility of the burial digenetic origin to explain the high occurrence of illite and low smectite mainly due to the illitization of smectite. Gradual increase in IS and smectite toward the Upper Cretaceous may indicate the gradual disappearance of deep burial diagenesis and the presence of the favorable conditions for the detrital input. The low thickness of the sediments of Upper Cretaceous and younger deposits also confirms the possibility of the detrital pedogenetic origin rather than the burial diagenesis. Smectite was proved to be of the montmorillonite type (dioctahedral). The higher occurrences of IS and smectite and its coexistence with some palygorskite in most parts of the Upper Cretaceous and younger deposits could indicate the prevailing of a semi-arid climate and hot seasonal droughts. Dominance of seasonal and semi-arid conditions extends to all Paleogene and Neogene sediments. Clay mineralogical data is suggested to be used along with other proxies to have a more reliable paleoclimate interpretations.
\end{abstract}

\section{INTRODUCTION}

The sedimentary basin of Kopet Dagh basin (KD) is situated in the north-east of Iran and extends to the south of Turkmenistan and the north of Afghanistan. Part of the KD basin in Iran is geographically located between $54^{\circ} 00^{\prime}$ and $61^{\circ} 14^{\prime} \mathrm{E}$ and $36^{\circ} 00^{\prime}$ and $38^{\circ} 16^{\prime} \mathrm{N}$ (Fig. 1). KD has been formed as an intracontinental basin after the closure of the Tethys Ocean following the Early Kimmerian orogeny (Berberian and King, 1981; Raisossadat, 2004). Detailed geological studies of the succession were carried out by geologists of the National Iranian Oil Company (NIOC) during the 1960s and 1970s (Raisossadat, 2004).

From the Jurassic up to the Eocene, relatively continuous sedimentation is recorded by five major transgressive-regressive sequences in the eastern KD. Subsidence began in the basin in the late Mid Jurassic (Afshar-Harb, 1979; Seyed-Emami and Alavi Naini, 1990; Seyed-Emami et al., 1996). The entire sedimentary sequences of the KD Basin begin from Jurassic to Late Tertiary comprise seventeen geological formations (Table 1). Kashafrud is the first formation dates back to Aalenian (Jurassic). Together with Bashkalate, Chamanbid and Mozduran they form the Jurassic formations of KD. A single megasequence embraces the bulk of the Lower Cretaceous sedimentary rocks. It begins with conglomerates and sandstones of the Shurijeh formation, and ends with dark gray shales and siltstones of the Sanganeh formation (Mortazavi et al., 2013)

Mineral types and abundances present in sediments and rocks can present significant information on the rock properties and sedimentary basin (Ritz et al., 2012). Clay mineral variation in sediments and sedimentary rocks may result from modifications to detrital sediments related to tectonically controlled changes in sediment source (Chamley, 1989), or from changes in the intensity of weathering or variations in depositional conditions depending on climatic conditions and sea level (Schieber, 1986; Li et al., 2000). Origin of the clay minerals includes weathering, and diagenesis (Hardy and Tucker, 1988). Smectite, illite, chlorite, kaolinite, palygorskite, sepiolite and mixed-layer illite-smectite are the common minerals found in the geological deposits. Based on the results of the study of the clay mineral assemblage in the Middle Jurassic sedimentary succession of the Kachchh Basin, India, the Bajocian to Middle Bathonian time interval is interpreted to represent subtropical climatic conditions with seasonal droughts and a moderate supply of terrigenous clastics to the basin. The Late Bathonian was a period with a semi-arid climate, hot seasonal droughts and a minor input of terrigenous clastics. The increase in kaolinite contents in the Callovian suggests a subtropical humid climate with less prominent seasonal droughts and a higher input of siliclastics into the basin accompanied by a higher 


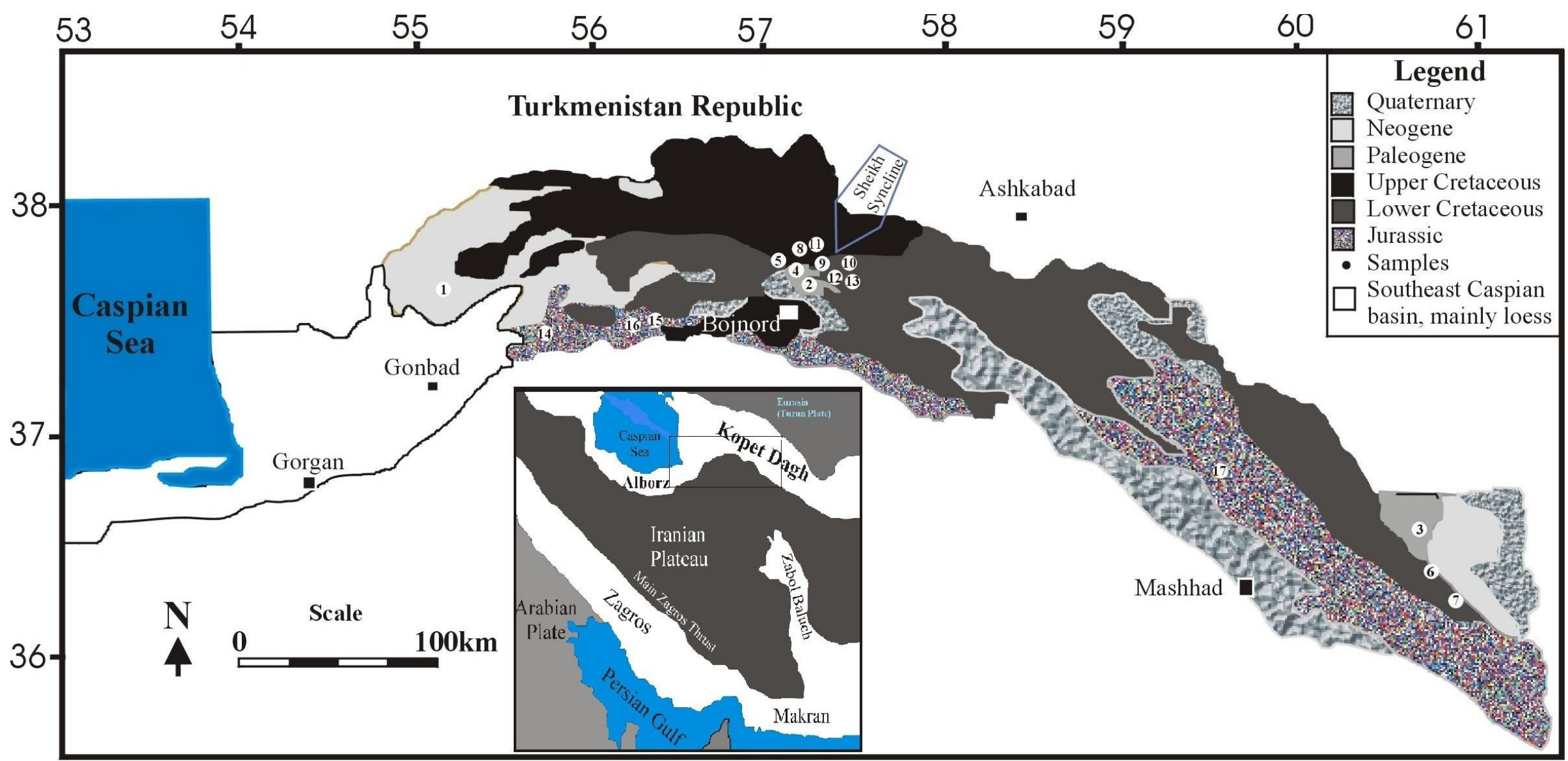

Fig. 1 Study area, geological map and the sites of the samples studied. 
Table 1 Geologic time and sites of the studied formations.

\begin{tabular}{|c|c|c|c|c|c|}
\hline System & Stage & Formation & No & $\begin{array}{c}\text { Elevation } \\
\text { above sea } \\
\text { level, } \mathbf{m}\end{array}$ & Sampling site \\
\hline \multirow{8}{*}{ Paleogene } & Pliocene & Aghchegil & 1 & 150 & $\begin{array}{l}\text { N } 37^{\circ} 34^{\prime} 20.3^{\prime \prime} \\
\text { E } 55^{\circ} 10^{\prime} 25.5^{\prime \prime}\end{array}$ \\
\hline & Upper Paleocene-Eocene & Khangiran & 2 & 1321 & $\begin{array}{l}\text { N } 37^{\circ} 34^{\prime} 27.3^{\prime \prime} \\
\text { E } 57^{\circ} 33^{\prime} 37.5^{\prime \prime}\end{array}$ \\
\hline & Paleocene & Chelkaman & 3 & 1102 & $\begin{array}{l}\mathrm{N} 36^{\circ} 40^{\prime} 18.3^{\prime \prime} \\
\text { E } 60^{\circ} 41^{\prime} 15.5^{\prime \prime}\end{array}$ \\
\hline & Lower Paleocene & Pesteligh & 4 & 1277 & $\begin{array}{l}\text { N } 37^{\circ} 34^{\prime} 23.8^{\prime \prime} \\
\text { E } 57^{\circ} 33^{\prime} 25.6^{\prime \prime}\end{array}$ \\
\hline & Maastrichtian & Kalat & 5 & 1249 & $\begin{array}{l}\text { N } 37^{\circ} 34^{\prime} 03.9^{\prime \prime} \\
\text { E } 57^{\circ} 33^{\prime} 41.5^{\prime \prime}\end{array}$ \\
\hline & Maastrichtian & Neizar & 6 & 1050 & $\begin{array}{l}\mathrm{N} 36^{\circ} 20^{\prime} 40.3^{\prime \prime} \\
\mathrm{E} 60^{\circ} 40^{\prime} 25.5^{\prime \prime}\end{array}$ \\
\hline & Santonian-Campanian & Abtalkh & 7 & 1190 & $\begin{array}{l}\mathrm{N} 36^{\circ} 18^{\prime} 43.3^{\prime \prime} \\
\text { E } 60^{\circ} 55^{\prime} 25.5^{\prime \prime}\end{array}$ \\
\hline & Turonian-Coniacian & Abderaz & 8 & 1232 & $\begin{array}{l}\text { N } 37^{\circ} 34^{\prime} 0.1^{\prime \prime} \\
\text { E } 57^{\circ} 33^{\prime} 37.5^{\prime \prime}\end{array}$ \\
\hline \multirow[t]{5}{*}{ Cretaceous } & Albian-Cenomanian & Aitamir & 9 & 1223 & $\begin{array}{l}\text { N } 37^{\circ} 33^{\prime} 35.5^{\prime \prime} \\
\text { E } 57^{\circ} 33^{\prime} 4.5^{\prime \prime}\end{array}$ \\
\hline & Albian & Sanganeh & 10 & 1053 & $\begin{array}{l}\text { N } 37^{\circ} 33^{\prime} 12.6^{\prime \prime} \\
\text { E } 57^{\circ} 30^{\prime} 56.4^{\prime \prime}\end{array}$ \\
\hline & Aptian & Sarcheshmeh & 11 & 1019 & $\begin{array}{l}\text { N } 37^{\circ} 27^{\prime} 39.3^{\prime \prime \prime} \\
\text { E } 57^{\circ} 39^{\prime} 22.6^{\prime \prime}\end{array}$ \\
\hline & Neocomian-Aptian & Tirgan & 12 & 1149 & $\begin{array}{l}\text { N } 37^{\circ} 31^{\prime} 38.9^{\prime \prime \prime} \\
\text { E } 57^{\circ} 21^{\prime} 01.6^{\prime \prime}\end{array}$ \\
\hline & Neocomian & Shurijeh & 13 & 1156 & $\begin{array}{l}\text { N } 37^{\circ} 31^{\prime} 45.4^{\prime \prime} \\
\text { E } 57^{\circ} 20^{\prime} 41.3^{\prime \prime}\end{array}$ \\
\hline \multirow[t]{4}{*}{ Jurassic } & Oxfordian-Kimmeridian & Mozduran & 14 & 903 & $\begin{array}{l}\text { N } 37^{\circ} 30^{\prime} 20.3^{\prime \prime} \\
\text { E } 55^{\circ} 38^{\prime} 25.5^{\prime \prime}\end{array}$ \\
\hline & Bathonian-Callovian & Chamanbid & 15 & 1568 & $\begin{array}{l}\text { N } 37^{\circ} 26^{\prime} 7.8^{\prime \prime} \\
\text { E } 56^{\circ} 33^{\prime} 36.4^{\prime \prime}\end{array}$ \\
\hline & Bajocian & Bashkalate & 16 & 1646 & $\begin{array}{l}\text { N } 37^{\circ} 24^{\prime} 59.4^{\prime \prime \prime} \\
\text { E } 56^{\circ} 29^{\prime} 29.8^{\prime \prime}\end{array}$ \\
\hline & Toarcian-Aalenian & Kashafrud & 17 & 1402 & $\begin{array}{l}\text { N } 36^{\circ} 55^{\prime} 20.3^{\prime \prime} \\
\text { E } 59^{\circ} 31^{\prime} 25.5\end{array}$ \\
\hline
\end{tabular}

nutrient influx (Fürsich et al., 2005). The presence of kaolinite, smectite, illite and chlorite in sediments of the Tethys area are the result of inheritance from soils and sediments subjected to a tropical or subtropical climate (Chamley, 1998; Bolle and Adatte, 2001). The presence of kaolinite in Lower Cretaceous materials of Alava Block, Spain is also attributed to inheritance from soils developed on rocks in the source area (Sanguesa et al., 2000).

Khormali et al. (2005) studied the clay mineral distribution of the southern Iran, i.e. Zagros geological rocks and concluded that kaolinite, smectite, chlorite, illite, palygorskite and illite-smectite mixed-layer minerals were present in the rocks studied. The results revealed that detrital input is possibly the main source of kaolinite, chlorite and illite, while in situ neoformation during the Tertiary shallow saline and alkaline environment could be the dominant cause of palygorskite occurrences in the sedimentary rocks. Smectite was also neoformed and transported into the marine realm.

The presence of a large amount of kaolinite in the Lower Cretaceous sediments of Zagros area was in accordance with the warm and humid climate of that period. Occurrence of high smectite in Upper Cretaceous sediments indicates the gradual shift from warm and humid to more seasonal climate. The occurrence of palygorskite and smectite and the disappearance of kaolinite in the late Palaeocene sediments indicate the increase in aridity. Dominance of palygorskite and sepiolite minerals in the Paleocene to Early Oligocene in Tunisia was reported by many researchers (Chamle, 1989; Adatte et al., 2002; Bolle and Adatte, 2001; Zaaboub et al., 2005).

Madhavaraju, et al. (2002) studied the Clay minerals of late Maastrichtian-early Palaeocene (Cretaceous-Tertiary) sedimentary rocks in the Cauvery Basin (southeastern India) and concluded that mixed-layer illite-smectites dominate the clay mineral content of the uppermost Maastrichtian of all areas, with elevated smectite, illite, palygorskite, sepiolite, kaolinite and chlorite occurring at intervals through the succession. They suggested arid conditions for the Late Cretaceous, followed by a period of warm and humid conditions at about the K/T boundary. Shoval (2004) studied the marine 


\begin{tabular}{|c|c|c|c|c|c|c|c|c|c|}
\hline \multirow[t]{3}{*}{ Stage } & \multirow[t]{3}{*}{ Formation } & \multirow{3}{*}{\multicolumn{3}{|c|}{ Major lithology }} & \multicolumn{5}{|c|}{ Thickness, m (NIOC Report, Afshar Harb, 1994) } \\
\hline & & & & & \multicolumn{2}{|c|}{ Thickness in KD basin } & \\
\hline & & & & & \multirow{2}{*}{$\begin{array}{c}\max \\
19\end{array}$} & \multirow{2}{*}{$\frac{\min }{19}$} & Khangiran 1 & led for gas exp & Gonbadli 3 \\
\hline Pliocene & Aghchegil & \multirow{7}{*}{ 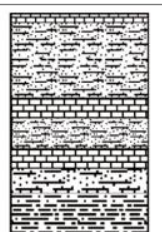 } & \multirow{2}{*}{$\begin{array}{l}\mathrm{Ag} \\
\mathrm{Kh}\end{array}$} & $\begin{array}{l}\text { yellow limestone, yellow } \\
\text { sandstone }\end{array}$ & & & \multirow{2}{*}{\multicolumn{3}{|c|}{ lack of sedimentation }} \\
\hline $\begin{array}{l}\text { Upper Paleocene- } \\
\text { Eocene }\end{array}$ & Khangiran & & & sandstone, calcareous shale & 850 & 145 & & & \\
\hline Paleocene & Chelkaman & & Chk & limestone, dolomite & 229 & 127 & 220 & 230 & 193 \\
\hline Lower Paleocene & Pesteligh & & Ps & shale, mudstone, sandstone & 424 & 126 & 55 & 110 & 140 \\
\hline Maastrichtian & Kalat & & $\mathrm{kt}$ & limestone, calcareous shale & 277 & 145 & 80 & 70 & 60 \\
\hline Maastrichtian & Neizar & & $\mathrm{Nz}$ & $\begin{array}{l}\text { glauconitic sandstone and } \\
\text { shale }\end{array}$ & 318 & 184 & 230 & 220 & 200 \\
\hline Santonian-Campanian & Abtalkh & & Abt & calcareous shale & 813 & 140 & 260 & 140 & 118 \\
\hline Turonian-Coniacian & Abderaz & 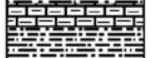 & Abd & $\begin{array}{l}\text { white chalky limestone, } \\
\text { calcareous shale }\end{array}$ & 350 & 188 & 440 & 510 & 430 \\
\hline Albian-Cenomanian & Aitamir & & At & $\begin{array}{l}\text { glauconitic sandstone, } \\
\text { glauconitic shale }\end{array}$ & 1000 & 73 & 420 & 480 & 480 \\
\hline Albian & Sanganeh & & Sn & shale & 740 & 740 & 210 & 263 & 211 \\
\hline Aptian & Sarcheshmeh & & $\mathrm{Sr}$ & marl, thin limestone and shale & 310 & 110 & 220 & 200 & 187 \\
\hline Neocomian-Aptian & Tirgan & & Ir & limestone, marl & 778 & 31 & 40 & 30 & 25 \\
\hline Neocomian & Shurijih & & Sh & shale, mudstone, sandstone & 1196 & 246 & 270 & 250 & 246 \\
\hline Oxfordian-Kimmeridian & Mozduran & & $\mathrm{Mz}$ & micritic limestone, dolomite & 1440 & 220 & & & \\
\hline Bathonian-Callovian & Chamanbid & I & $\mathrm{Ch}$ & micritic limestone, marl & 1722 & 316 & & rilling stopped & \\
\hline Bajocian & Bashkalate & 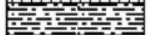 & $\mathrm{Ba}$ & calcareous shale & 460 & 140 & & & \\
\hline Toarcian-Aalenian & Kashafrud & 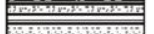 & & shale, sandstone & 1800 & 1800 & & & \\
\hline & & 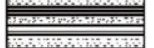 & $\mathrm{Ka}$ & $\begin{array}{l}\text { Thickness (Tertiary \& Upper } \\
\text { Cretaceous) }\end{array}$ & 2411 & 983 & 1705 & 1760 & 1621 \\
\hline & & 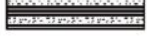 & & $\begin{array}{l}\text { Thickness (Lower Cretaceous \& } \\
\text { Jurassic) }\end{array}$ & 8446 & 3603 & - & - & - \\
\hline & & & & SUM & 10857 & 4586 & - & - & - \\
\hline
\end{tabular}

Fig. 2 Lithology and the thickness of the deposits in Kopet Dagh basin.

sedimentation along the margin of the southeastern Neo-Tethys, and concluded that Senonian and the Eocene is dominated by smectitic IS (mixed-layer illite/smectite rich in smectite layers) accompanied by kaolinite, palygorskite and occasional sepiolite.

Haywood et al. (2004) reports the presence of high precipitation rates during all seasons with little evidence for prolonged drought and the average precipitation rate of about 4-8 $\mathrm{mm} /$ day per month during the Early Cretaceous (Barremian) in the Weald (SE England). Smectitic minerals are the dominant clay species of the Cenomanian-Campanian Late Cretaceous sediments (Deconinck et al., 2005). There are no studies on the clay mineralogy of KD basin. The main objectives of this study were therefore to document the origin and distribution of clay minerals in different geological formations, and to reconstruct the paleoclimate of the area.

\section{MATERIALS AND METHODS}

\subsection{SITE DESCRIPTION AND SAMPLING}

The sites of the samples located by GPS and the general information on the deposits are shown in Table 1 and Figure 1. All the major 17 geological formations together with their different subtypes were distinguished precisely in different regions with similar tectonic settings and sampled for the laboratory analysis. Non-weathered representative rock samples were powdered prior to the analyses.

\subsection{GEOLOGY}

Figure 2 presents a brief lithology of all the 17 geological formations of the KD basin. Sedimentation starts with Kashafrud formation in the KD. Bashkalate, Chamanbid and Mozduran are other formations mainly formed in relatively deep marine environments. The Shurijeh formation belongs to the Neocomian and was formed as a result of sea retreatment (Afshar-Harb, 1979). Afshar-Harb (1994) reports a depositional gap i.e. continental rather than marine environment in the beginning of Cretaceous in the most parts of the KD basin. The Shurijeh formation is a reddish formation deposited in a delta, river, sebkha or a marsh environment. The continental-marsh environment gradually replaced with a deep marine regime and Tirgan, Sarcheshmeh, and Sanganeh shales were formed. There was a retreatment and subsidence of the sea during Cenomanian and thus Aitamir formation is considered as the deposits of the retreated sea. From this period on there was a depositional gap and later in Turonian till Maastrichtian, Abderaz, Abtalkh, Neizar and Kalat formations were deposited. In general regressivetransgressive movements of the sea were repeated many times during the Cretaceous. According to Zahedi (1976), the Zagros area underwent a relatively moderate orogenic phase (attenuated Laramian phase) near the end of the Cretaceous and the beginning of the Eocene, characterized by folding, emergence and erosion. Similar to the other parts of Iran, Laramian movements affected also the KD basin and Pesteligh formation was entirely formed in a continental environment. It is comparable with Sachun formation of Zagros both show a presence of oxidative continental environment in the beginning of Paleocene. Chelkaman and Khangiran are the other two formations in Tertiary. The regressive movements continued to the Neogene in which Aghchegil deposits were formed. 


\subsection{LABORATORY ANALYSES}

\subsubsection{XRD ANALYSIS}

Eighty five samples for XRD analysis have been prepared. The removal of chemical cementing agents and separation of the clay fractions were done according to the methods of Kittrick and Hope (1963) and Jackson (1975), but with some modifications. Samples were ground and treated with sodium acetate $(\mathrm{pH} 5)$ to remove carbonates. The addition of $1 \mathrm{~N}$ sodium acetate was continued until no effervescence was observed with $1 \mathrm{~N} \mathrm{HCl}$. The neutralization was performed in a water bath at $80^{\circ} \mathrm{C}$. The organic matter was then oxidized by treating the carbonate-free soils $\mathrm{H}_{2} \mathrm{O}_{2}$, and digestion in a water bath. To prevent from modifications of the swelling minerals, only $5 \mathrm{ml}$ $\mathrm{H}_{2} \mathrm{O}_{2}(20 \%)$ was used. Free iron oxides were removed from samples by the citrate dithionate method of Mehra and Jackson (1960). The iron-free samples were centrifuged at $750 \mathrm{rpm}$ for 5.4 minute and the clay separates were removed and studied by a Bruker D8 X-ray diffractometer using $\mathrm{CuK} \alpha$ radiation $(40 \mathrm{kV}$ and $30 \mathrm{~mA}$ ), a step size of $0.02^{\circ}$ and a time per step of 1 s. X-ray diffractograms were obtained from $\mathrm{Mg}$ saturated soil clays both before and after glycerol treatment. $\mathrm{K}$ saturated samples were also studied by $\mathrm{X}$-ray diffraction after drying at room temperature and after heating at $330{ }^{\circ} \mathrm{C}$ and $550{ }^{\circ} \mathrm{C}$ for $2 \mathrm{~h}$. Equal concentrations of clay suspensions were used for all samples in order to have a more reliable comparison between relative peak intensities of different samples. To identify kaolinite in the presence of trioctahedral chlorite, samples were also treated with $1 \mathrm{~N} \mathrm{HCl}$ at $80^{\circ} \mathrm{C}$, overnight (Moore and Reynolds, 1989). The percentages of the clay minerals were estimated according to Johns et al. (1954) based on the relative peak areas of the glycerol solvated treatments using EVA software version 2002. To distinguish montmorillonite from nantronite, saponite, and beidellite Li saturation and heat treatment was used (Moore and Reynolds, 1989). In this experiment montmorillonite irreversibly collapses after $\mathrm{Li}$ saturation and heat treatment. The sample was $\mathrm{Li}$ saturated and the excess $\mathrm{LiCl}$ removed by multiple washings with water followed by silver nitrate tests to ascertain the absence of chloride. The sample was mounted on an opaque fused silica slide and heated to $300{ }^{\circ} \mathrm{C}$ for $12 \mathrm{~h}$. the slide was then saturated with glycerol and analyzed immediately on the diffractometer.

\subsubsection{THIN SECTION STUDIES}

Thin sections of about $10 \mathrm{~cm}^{2}$ were also prepared from rock samples using standard techniques. The total of 30 thin sections was prepared and studied using petrographic microscope.

\subsubsection{HIGH RESOLUTION MICROSCOPIC STUDIES}

For TEM studies of about 25 samples, suspensions of 1:500 ( $\mathrm{g}$ dry clay/ $\mathrm{mL}$ water) were prepared from dried rock clay particles and $100 \mu \mathrm{L}$ of the suspension were dried on 200-mesh formvarcoated $\mathrm{Cu}$ grids under a heat lamp for $25 \mathrm{~min}$ and examined using a LEO 906E transmission electron microscope. For SEM studies, small samples $\left(\sim 1 \mathrm{~cm}^{3}\right)$ were studied by scanning electron microscopy (SEM). Rock samples of all deposits were mounted on $\mathrm{Al}$ stubs using double- sided tape and carbon paste, then coated with Au and examined chemically using a LEO SEM.

\section{RESULTS}

\subsection{XRD STUDIES}

Type and the relative abundances of clay minerals in the studied rocks are presented in Table 2. Illite-Smectite mixed layer mineral (IS), Smectite, kaolinite, chlorite, illite, palygorskite are the major clay minerals of the studied sedimentary rocks. Kashafrud, Bashkalate, Chamanbid and Mozduran are the four formations of Jurassic. They all show relatively similar type of clay minerals as well as similar abundances. Illite is the dominant clay mineral of the Jurassic formations. Smectite and IS occur in low quantities. There is an increasing trend in the IS toward the end of the Jurassic and early Cretaceous i.e. Shurijeh formation (Fig. 3). A peak at $17.9 \AA$ in the glycerol treatment is not always indicative of pure smectite, especially considering the weak intensities of the $17 \AA$ reflection of diffractograms in Figures $3 a$ and 3b (Moore and Reynolds, 1989). Diffractograms in Figures $3 a$ and $3 b$ are most probably R0 IS mixed layer (perhaps R1), for that a deconvolution of the $001 / 002$ around $9-9.5 \AA$ and $002 / 003$ around $5.5-5 \AA$ is highly recommended. Peaks $10,3.58$ and $3.54 \AA$ in $\mathrm{Mg}$ treatment are related to illite, kaolinite and chlorite respectively.

This increase is clearly observed by a high peak of $18.2 \AA$ in the glycerol treated pattern. Kaolinite content does not differ significantly with that of Jurassic. Illite however decreases gradually (Table 2). Chlorite occurs in minor amounts.

Aitamir, Abderaz, Abtalkh, Neizar, and Kalat are the five deposits belonging to the Upper Cretaceous. Whilst illite is decreasing, IS and smectite increase sharply in all the Upper Cretaceous units with special strong peak of XRD in Aitamir i.e. beginning of the Upper Cretaceous (Fig. 3). Very strong $14.8 \AA$ peak in $\mathrm{Mg}$ saturated sample shifting to $18.1 \AA$ is related to well crystallized smectite and also IS. This peak shifts gradually to $12.3 \AA$ by potassium $(\mathrm{K}), 12$ by $\mathrm{K}$ and $330{ }^{\circ} \mathrm{C}$ heating and finally to $10 \AA$ in $\mathrm{K}$ and $550{ }^{\circ} \mathrm{C}$ heat treatment. XRD of the other samples of the Upper Cretaceous follow almost the similar trend with the smectite peaks of lower strength and sharpness compared to that of Aitamir.

Pesteligh, Chelkaman and Khangiran are the three rock types of Paleogene. As for the Upper Cretaceous, IS and is the dominant clay mineral of all three formations. Its abundance is higher in Khangiran i.e the Upper Paleogene compared to the other two formations. Figure $3 \mathrm{~d}$ shows XRD patterns of 
Table 2 Average contents of clay minerals in the studied formations.

\begin{tabular}{lrrrrrr}
\hline $\begin{array}{l}\text { Geological } \\
\text { Formations }\end{array}$ & I* & C & IS & K & P & S \\
\hline & & & & & & \\
& & & & & & \\
\hline Aghchegil & 6 & 5 & 50 & 4 & 0 & 35 \\
Khangiran & 5 & 3 & 43 & 2 & 7 & 40 \\
Chelkaman & 37 & 6 & 26 & 4 & 7 & 20 \\
Pesteligh & 18 & 10 & 40 & 5 & 7 & 20 \\
Kalat & 7 & 6 & 47 & 5 & 5 & 30 \\
Neizar & 16 & 14 & 39 & 5 & 6 & 20 \\
Abtalkh & 10 & 9 & 40 & 4 & 7 & 30 \\
Abderaz & 3 & 6 & 50 & 2 & 8 & 31 \\
Aitamir & 5 & 3 & 53 & 2 & 7 & 30 \\
Sanganeh & 30 & 30 & 15 & 15 & 0 & 10 \\
Sarcheshmeh & 30 & 15 & 15 & 21 & 0 & 19 \\
Tirgan & 40 & 9 & 10 & 20 & 0 & 21 \\
Shurijeh & 43 & 10 & 10 & 12 & 0 & 25 \\
Mozduran & 55 & 10 & 0 & 20 & 0 & 15 \\
Chamanbid & 50 & 15 & 0 & 25 & 0 & 10 \\
Bashkalate & 65 & 15 & 0 & 20 & 0 & 0 \\
Kashafrud & 55 & 15 & 2 & 25 & 0 & 3 \\
\hline
\end{tabular}

* I: Illite, C: Chlorite, IS: Interstratified mixed layer, K: Kaolinite, P: Palygorskite, S: Smectite

Khangiran formation. As seen illite, chlorite and kaolinite are scarce in this sample and IS and smectite peak is very sharp and strong. Aghchegil is the only deposit of the Neogene and also the last deposition occurred in KD sedimentary basin. IS is the dominant clay mineral present. The IS peak however, is less sharp and strong compared to the Khangiran formation. In general, illite is the dominant mineral in the Jurassic and Lower Cretaceous formations. Illite and Kaolinite show decreasing trends from the beginning of upper Cretaceous (Cenomanian). Chlorite occurs in low amounts in all formations and does not follow any specific trend. IS however is considered as the highly variable clay mineral in the studied deposits. As a general trend, its abundance in the Jurassic and Lower Cretaceous sediments is relatively low compared to the Upper Cretaceous, Tertiary and Neogene sediments. A main feature of the IS variation trend is its huge increase with the start of Cenomanian, i.e., Upper Cretaceous (Aitamir formation) which continues with the similar variation to the Upper Cretaceous, Tertiary and Neogene. There exists however some fluctuations in the IS variation trend. It shows some increasing and decreasing trends mainly observed in Shurijeh (Neocomian, start of Cretaceous), and Aitamir (Cenomanian, start of Upper Cretaceous). In the XRD patterns, no $10.5 \AA$ peak of palygorskite was detected clearly. Submicroscopic studies therefore were carried out to detect even small quantities of this mineral. To distinguish montmorillonite from nantronite, saponite, and beidellite, $\mathrm{Li}$ saturation and heat treatment was used (Moore and Reynolds, 1989) (Fig. 4). As seen $17.86 \AA$ peak has irreversibly collapsed after $\mathrm{Li}$ saturation and heat treatment. This is characteristic for montmorillonite. Speculation is that $\mathrm{Li}$ ions migrate into the octahedral sheet and neutralize the layer charge if the charge is due to the octahedral substitution.

The elimination of charge converts montmorillonite to a pyrophyllite-like mineral that does not expand upon treatment with water, glycerol, or ethylene glycol.

\subsection{THIN SECTION STUDIES}

Figure 5 presents some selected thin sections of the samples studied. Shurijeh formation is mainly composed of medium grain calcareous ferrogenous submature litharenite. The main cement in the section is calcareous and iron oxides (15\%). Ferrogenous biosparites are observed in Sarcheshmeh formation (Fig. 5b). The matrix is partly micrite replaced by sparite cements surrounding bioclasts. The whole section was affected by replacement and hematitization. Fine grain calcareous- ferrogenous immature feldspatic litharenite forms the main composition of the Aitamir formation (Fig. 5c). Carbonate and Fe oxide are the major cements which occupy $30-35 \%$ of the sample space. Glauconite fragments are observed in the whole section. Fine grain calcareous immature sublitharenite is the main composition of Khangiran formation (Fig. 5d). Cementing agent is of carbonate type occupying 20$25 \%$ of the sample. The feldspar weathering at the center of the slide is the probable precursor for the clay minerals formation.

\section{DISCUSSIONS \\ 4.1. ORIGIN AND DISTRIBUTION OF CLAY MINERALS}

Clay mineral variation in sediments and sedimentary rocks may result from modifications to detrital sediments related to tectonically controlled changes in sediment source (Chamley, 1989), or from changes in the intensity of weathering or variations in depositional conditions depending on climatic conditions and sea level (Schieber, 1986). Chamley (1998) and Bolle and Adatte (2001) provided convincing evidence that the presence of kaolinite, smectite, illite and chlorite in sediments of the Tethys area are the result of inheritance from soils and sediments subjected to a tropical or subtropical climate. Illite and chlorite are considered common byproducts of weathering reactions with low hydrolysis typical of cool to temperate and/or dry climates ( $\mathrm{Li}$ et al., 2000). Kaolinite is generally a by-product of highly hydrolytic weathering reactions in perennially warm humid climates and its formation requires a minimum temperature of $15^{\circ} \mathrm{C}$. Khormali et al. 


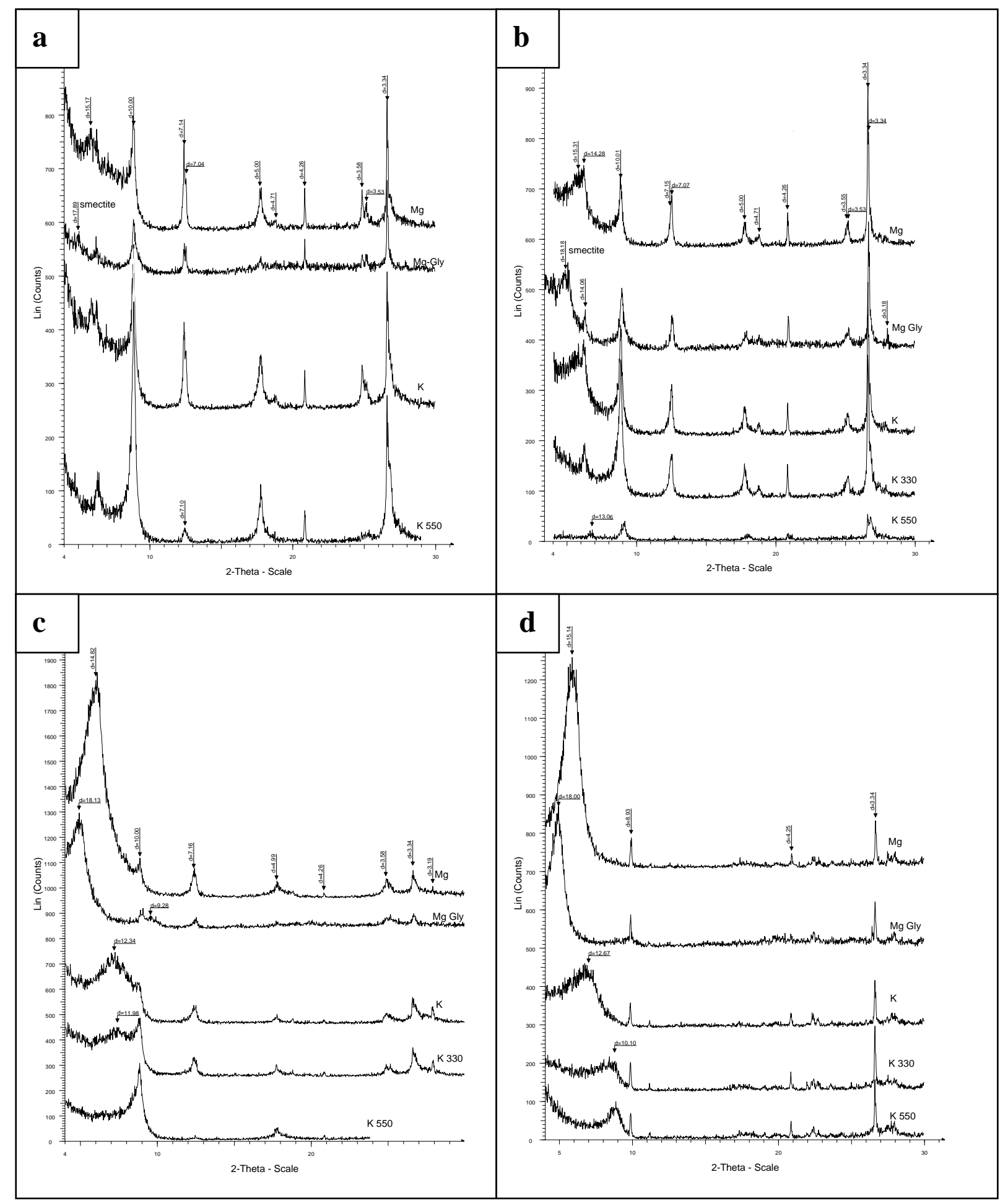

Fig. 3 XRD patterns of the Chamanbid (a), Shurijeh (b), Aitamir (c) and Khangiran (d) formations.

(2005) reported that detrital input is possibly the main source of kaolinite, smectite, chlorite and illite, while in situ neoformation during the Tertiary shallow saline and alkaline environment could be the dominant cause of palygorskite occurrences in the sedimentary rocks of southern Iran. In the KD Basin presence of large amounts of IS and smectite especially in the Upper Cretaceous could be related to its pedogenic formation during the transgressive sea and warm together with alternate arid period. In contrast to the southern Iran the deep burial diagenesis could be the major origin of the clay minerals in the Jurassic and parts of the
Lower Cretaceous in KD Basin. The thick sediments of the Lower Cretaceous and Jurassic (up to $8000 \mathrm{~m}$, Figure 2) suggest the presence of possible burial digenetic origin for higher occurrence of illite and decrease in IS due to illitization of smectite (Ruarri et al., 2008; Kemp, 2008). The primary reactions of marine diagenesis involve the conversion of smectite to mica or chlorite under burial temperatures of around $80-100^{\circ} \mathrm{C}$ (Larsen and Chilinger, 1983). Depending on the geothermal gradient and lithology, Smectite mostly exists in sediments that have undergone burial at depths lower than $4 \mathrm{~km}$ (Weaver, 


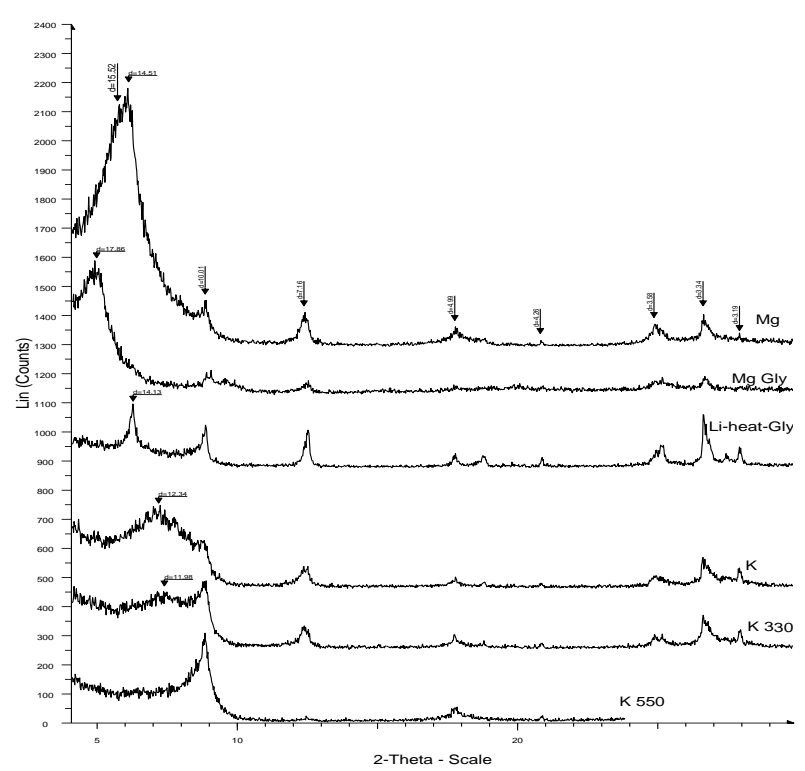

Fig. 4 Li saturated and heat treated sample showing the montmorillonitic type of smectite.

1959). Illite is therefore the most abundant mineral at depths greater than $4 \mathrm{~km}$ followed by lesser amounts of smectite, chlorite, and kaolinite.

Smectite is scarce in sediments older than Mesozoic (230 million years old) largely because of changes for metamorphism or diagenesis increase with age. While kaolinite and smectite minerals may be stable at low temperature, illite and quartz are stable even at higher diagenetic temperatures. Dioctahedral smectite undergoes progressive replacement by illite at temperatures greater than about $70-90{ }^{\circ} \mathrm{C}$ (Worden and Burley, 2003; McKinley et al., 2003). It is possible that illite with minor smectite typically results from smectite precursors whereas pure illite results from direct precipitation from pore waters with $\mathrm{K}$ derived from breakdown of other alumimosilicate minerals. $\mathrm{K}, \mathrm{Mg}, \mathrm{Fe}$ and $\mathrm{Al}$ are removed from sea water by smectite during diagenesis (Roberson and Lahann, 1981). As the reaction proceeds, $\mathrm{Al}$ is thought to enter the tetrahedral sheet, thereby increasing the layer charge and the selectivity for $\mathrm{K}$ and $\mathrm{Mg}$. The expelled silica precipitates as a cementing agent and later crystallizes into quartz. An alternative mechanism for diagenesis has been proposed in which smectite particles are thought to dissolve completely, with their constituents recrystallizing nearby as illite particles (Nadeau et al., 1984; Ahn and Peacor, 1986).

Gradual increase in IS and smectite toward Upper Cretaceous can indicate to the presence of prevailing conditions for detrital origin and absence of deep burial diagenesis in the KD basin. Dominance of IS from the Cenomanian to the end of the sedimentary sequence of KD and its coexistence with smectite minerals point to their pedogenic formation and their detrital input into the sedimentary environment during Upper Cretaceous and Tertiary and younger periods. According to the XRD and XRF analyses, smectite is

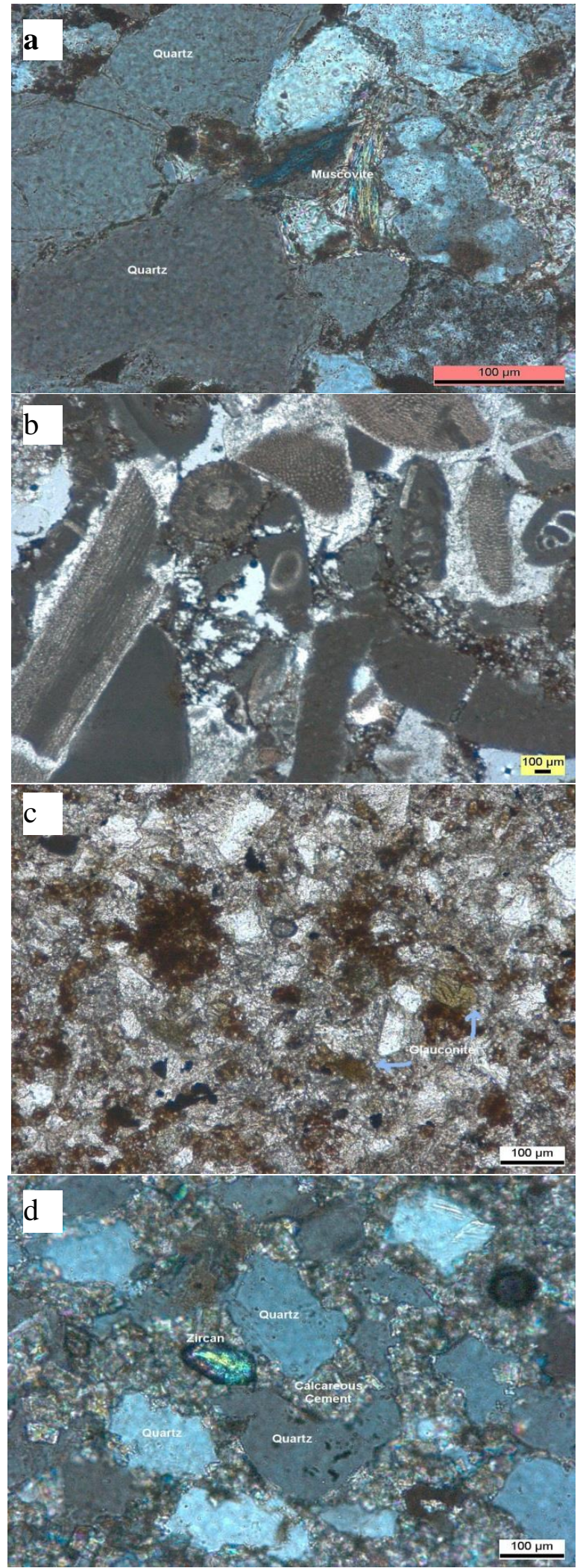

Fig. 5 Thin section of a: Shurijeh formation (XPL), b; Sarcheshmeh formation (PPL), c; Aitamir formation (PPL) and d; Khangiran formation (XPL). 
dioctahedral type and is most probably montmorillonite (Fig. 4, Table 3). As seen in Table 3, which is the elemental analysis of the clay fraction of Aitamir rock unit, presence of significant amounts of tetrahedral $\mathrm{Al}$, absence of $\mathrm{Li}, \mathrm{Zn}$ and high $\mathrm{Mg}$ (as for trioctahedral types i.e. hectorite, sauconite and saponite respectively), low $\mathrm{Fe}^{3+}$ (as for dioctahedral nantronite), complete shift of $14 \mathrm{~A}^{\circ}$ peak to $18 \mathrm{~A}^{\circ}$ in the glycerol treatment (in case of beidellite it does not shift to $18 \mathrm{~A}^{\circ}$ ) and the irreversible collapse of $17.86 \AA$ peak has after Li saturation and heat treatment are the indications of montmorillonite. $\mathrm{K}$ and $\mathrm{Fe}$ could be related to impurities of glauconite as shown in the thin section (Fig. 5). As pointed out by Robert (1973), the neoformed soil smectites are probably closer to the true montrnorillonites, characterized by a low tetrahedral charge, than to the beidellites.

As seen in Figure 6, unlike XRD, TEM studies were proved to be a useful tool to monitor even small quantities of palygorskite. As for Zagros area of southern Iran, palygorskite was observed in the KD basin (Khormali and Abtahi, 2003; Khormali et al., 2005). Palygorskite and sepiolite clay minerals were formed in perimarine environments where continental alkaline waters are concentrated by evaporation leading to solutions rich in $\mathrm{Si}$ and $\mathrm{Mg}$ which favor their formation (Pletsch et al., 1996). The presence of palygorskite and sepiolite in the Tertiary sediments of the southern margin of Tethys has been related to their authigenic formation in shallow saline and At $\mathrm{P} / \mathrm{ET}^{\circ}$ values $>0.4$, palygorskite transforms to smectite. Coexistence of palygorskite with smectite points to their transformation origin and favorable conditions were present in the KD environment for the formation of this fibrous clay mineral. The prevailing environment was also favorable for the formation and stability of smectite. Unlike to the southern Iran, palygorskite was observed in low amounts and only by high resolution TEM studies. Palygorskite is not stable under burial diagenesis conditions and the low occurrence of this fibrous mineral especially down to the lower Cretaceous can be explained by contamination (Table 3). The smaller amounts of this mineral in the Upper Cretaceous and Tertiary however, could be explained by its pedogenic formation.

\subsection{PALEOCLIMATIC IMPLICATIONS}

Figure 7 summarizes the environmental conditions based on the clay mineral data. Starting from the Jurassic the main feature is the dominance of illite in the whole Jurassic and Lower Cretaceous. As discussed earlier, thick sediments of the Tertiary and Lower Cretaceous (up to 8000 m, Figure 2) suggest to the burial diagenetic origin for the presence of high illite due to illitization of IS and smectite and hence the clay mineral distribution in these sediments cannot be used directly as climatic indicators. From Upper Cretaceous however, where the overall thickness of the deposits $(<1700 \mathrm{~m})$ is low enough to allow
Table 3 Major element analysis of the clay fraction of the two selected samples from Aitamir rock unit.

\begin{tabular}{lcc}
\hline \multirow{2}{*}{ composition } & \multicolumn{2}{c}{ Content $(\%)$} \\
\cline { 2 - 3 } & $\begin{array}{c}\text { Aitamir } \\
\text { Sandstone }\end{array}$ & $\begin{array}{c}\text { Aitamir } \\
\text { Shale }\end{array}$ \\
\hline $\mathrm{SiO}_{2}$ & 72.15 & 70.98 \\
$\mathrm{Al}_{2} \mathrm{O}_{3}$ & 11.21 & 10.04 \\
$\mathrm{Fe}_{2} \mathrm{O}_{3}$ & 3.24 & 3.17 \\
$\mathrm{CaO}$ & 4.73 & 3.89 \\
$\mathrm{Na}_{2} \mathrm{O}$ & - & 1.97 \\
$\mathrm{~K}_{2} \mathrm{O}$ & 1.94 & 2.24 \\
$\mathrm{MgO}$ & 1.19 & 1.07 \\
$\mathrm{TiO}_{2}$ & 0.392 & 0.524 \\
$\mathrm{MnO}$ & 0.078 & 0.054 \\
$\mathrm{P}_{2} \mathrm{O}_{5}$ & 0.091 & 0.283 \\
\hline
\end{tabular}

stabilization of the pedogenically formed clay minerals, they can be more reliably used as climatic indicators due to the absence of digenesis. The high appearance of IS and smectite and the occurrence of low amounts of palygorskite in the Lower Cretaceous/Upper Cretaceous boundary might indicate to the gradual prevailing of a semi-arid climate, hot seasonal droughts and a minor input of terrigenous clastics (Khormali et al., 2005; Fürsich et al., 2005). There was a transgressive and regressive sea fluctuation during late Cenomanian and Aitamir formation is considered as deposits of the retreated sea (Afshar-Harb, 1979; Raisossadat, 2004; Fig. 7). This is also in agreement with the findings of Robert et al. (2014) who report that Aitamir formation was deposited in a shallow open-marine environment that is bordered by local erosion and is considered as the main hiatus occurred in the Cretaceous sedimentary history of Kopet Dagh basin. Low sea levels are generally associated with increased terrigenous influx, low kaolinite/chlorite+mica ratios. Less humid climates coincide with low sea levels and warm/humid climates with high sea levels (Li et al., 2000). Marked increase in IS and smectite shown by a sharp and strong $18 \AA$ peak could be related to the transgressive environment during late Cenomanian (Fig. 3). Palygorskite appearance also confirms the presence of aridity although in low amounts (Fig. 6). Clay mineral contents across the Lower-Upper Cretaceous boundary therefore suggest a diminution of seasonality at the boundary with possibly semi-arid conditions. From this period again there was a depositional gap and Later in the Turonian till Maastrichtian, Abderaz, Abtalkh, Neizar and Kalat formations were formed. The clay mineral distribution is still showing the dominance of IS and smectite and presence of some palygorskite (Fig. 5). The same results were also reported by Madhavaraju, et al. (2002) for southeastern India. In general, decreasingincreasing trends of the sea level repeatedly occurred during the Cretaceous. 

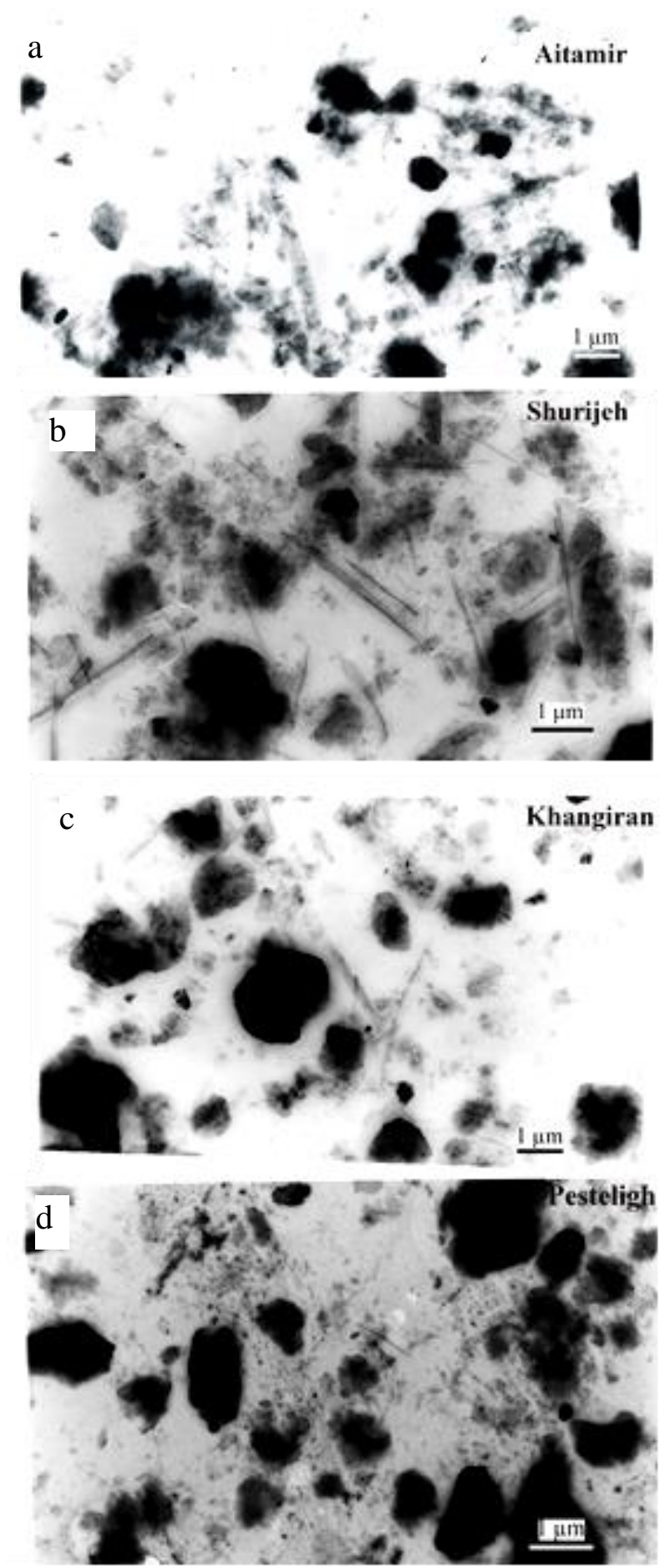

Fig. 6 TEM micrographs of a: Aitamir, b: Shurijeh, c: Khangiran and $\mathrm{d}$ : Pesteligh formations. Palygorskite fibers are observed in all samples.

Deconinck et al. (2005) also reports that the Cenomanian-Campanian Late Cretaceous sediments (including chalks from the Anglo-Paris Basin as well as coeval limestones and shales from the Tethyan realm and the Atlantic Ocean) comprise dominant smectitic minerals. In contrast to Zagros as studied by Khormali et al. (2005) showing complete depositional sequences, there were only few depositional periods in KD during Tertiary and only three formations were formed in Paleocene and Pliocene. Thus there is a big depositional gap from Paleocene to Pliocene in KD resulting in the uncertain climatic interpretations. The dominance of smectite still appears in both Paleogene and Neogene. As shown in Figure 6, palygorskite was observed almost in all the Upper Cretaceous and Tertiary deposits of KD. Shallow water and high temperature increase the $\mathrm{pH}$ and consequently enhance $\mathrm{Si}$ solubility and is responsible for the formation of palygorskite. The cut off of the Tethys Sea in the end of Cretaceous and its retreatment as reported by Zahedi (1976) probably started from the northern parts i.e. KD area. This could explain the absence of depositional environment from Palocene till Pliocene in KD region. Meanwhile there was a shallow saline lake in the Central and southern Iran associated with very high palygorskite. Low amount of Palygorskite was reported for Paleocene sediments of Southern Iran and the Prevailing climate was reported as seasonal and semi-arid (Khormali et al., 2005), which is the same for Paleocene sediments of KD.

The last KD sediment i.e. Aghchegil of Pliocene is still dominated by IS and smectite comparable to Zagros in which palygorskite was present. The condition of shallow saline lake environment during Pliocene was not either present or favorable as for the Zagros in KD for the formation of high amounts of fibrous minerals. Clay mineralogical variation diagram presented by Boggs (2006) shows that kaolinite decreases from Mesozoic to Cenozoic while smectite has the reverse trend. Our findings in the Kopet Dagh section are in line with this data.

\section{CONCLUSIONS}

The results revealed that deep burial diagenesis and detrital input were both responsible for the transformations of the clay minerals. The thick sediments (up to $8000 \mathrm{~m}$ ) of the Lower Cretaceous and Jurassic suggest the possibility of the burial digenetic origin to explain the high occurrence of illite and low smectite mainly due to illitization of smectite. Formation of high IS and smectite in the Upper Cretaceous and younger sediments can be explained by their pedogenetic detrital formation in the shallow sediments. Marked increase in IS and smectite during late Cenomanian is probably the most striking feature of the KD sedimentary environment. IS and smectite were the dominant clay minerals in all Paleogene and Neogene sediments.

In the study area, the higher occurrences of IS and smectite and its coexistence with some palygorskite in most of the Upper Cretaceous and younger deposits indicate to the prevailing of a semiarid climate, hot seasonal droughts. Dominance of seasonal and semi-arid conditions extends to all Paleogene and Neogene sediments.

Clay mineralogical studies can be usefully applied to monitor paleoclimate. However care should be taken since clay minerals occurrences could not only be related to pedogenesis, but also be of diagenetic origin not to have direct relation to paleoclimate. 


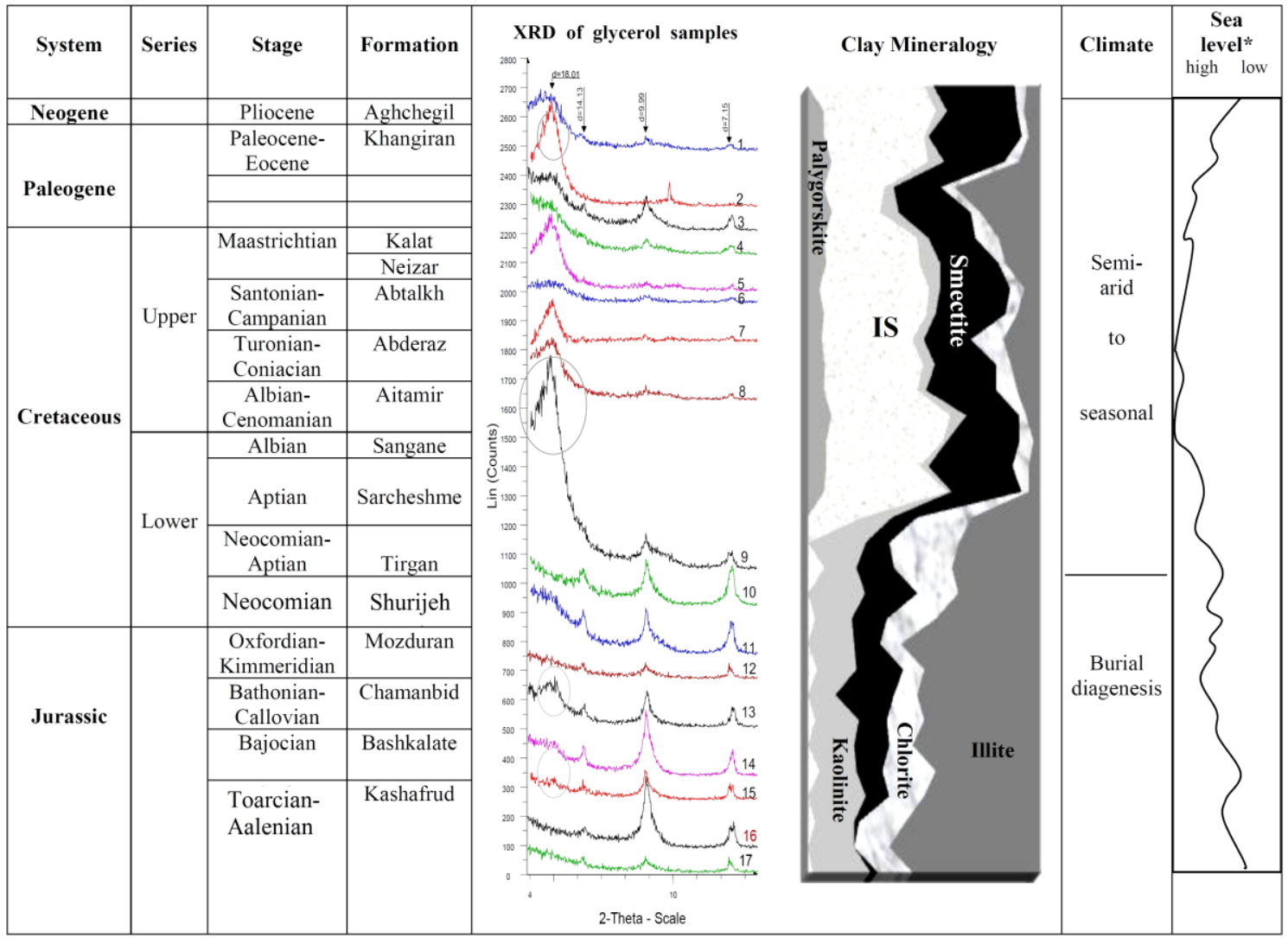

Fig. 7 Environmental conditions in the Kopet Dagh Basin based on the clay mineral data (P: Palygorskite; IS: Interstratified Mixed Layer; * Haq et al., 1987)

\section{ACKNOWLEDGEMENTS}

The authors would like to thank Gorgan University of Agricultural Sciences and Natural Resources University Research Council for financial support. We also appreciate the valuable comments of Prof. Reza Mussavi Harami, Dept. of Geology, Ferdowsi University of Mashhad, Iran and Prof. Thierry Adatte, Institute of Earth Sciences, University of Lausanne, Switzerland.

\section{REFERENCES}

Adatte, T., Keller, G. and Stinnesbeck, W.: 2002, Late Cretaceous to early Paleocene climate and sea-level fluctuations: the Tunisian record. Palaeogeography, Palaeoclimatology, Palaeoecology, 178, 165-196. DOI: 10.1016/S0031-0182(01)00395-9

Afshar-Harb, A.: 1979, The stratigraphy, tectonics and petroleum geology of the KD region, Northern Iran. Doctoral Imperical College of Science and Technology Thesis. University of London, $316 \mathrm{pp}$.

Afshar-Harb, A.: 1994, Geology of KD. In: Hushmandzadeh, A. (Ed.), Treatise on the Geology of Iran. Geological Survey of Iran, Tehran, 275 pp., (in Persian).

Ahn, J.H. and Peacor, D.R.: 1986, Transmission and analytical electron microscopy of the smectite-to-illite transition. Clays Clay Miner, 34, 165-179.

Berberian, M. and King, G.C.P.: 1981, Towards a palaeogeography and tectonic evolution of Iran. Canadian Journal of Earth Science, 18, 210-265.

DOI: $10.1139 / \mathrm{e} 81-019$
Boggs, S. Jr.: 2006, Principles of sedimentology and stratigraphy $\left(4^{\text {th }}\right.$ edition). Pearson Prentice Hall Pearson Education, Inc. 653pp.

Bolle, M.P. and Adatte, T.: 2001, Palaeocene-early Eocene climate evolution in the Tethyan realm: clay mineral evidence. Clay Miner., 36, 249-261. DOI: $10.1180 / 000985501750177979$

Chamley, H.: 1998, Clay mineral sedimentation in the ocean. In: Paquet H., and N. Clauer (eds.), Soils and Sediments (Mineralogy and Geochemistry), SpringerVerlag, Berlin, 269-302.

Chamley, H.: 1989, Clay sedimentology, 623 pp.

Day-Stirrat, R.J., Alpin, A.C., Rodo, J. and Van der Pluijm, B.: 2008, Diagenetic reorientation of phyllosilicate minerals in Paleogene mudstones of the Podhale basin, Southern Poland. Clays Clay Miner., 56, 100111. DOI: 10.1346/CCMN.2008.0560109

Deconinck, J.F., Amédro, F., Baudinc, F., Godetd, A., Pellenarda, P., Robaszynskie, F. and Zimmerlind, I.: 2005, Late Cretaceous palaeoenvironments expressed by the clay mineralogy of Cenomaniane-Campanian chalks from the east of the Paris Basin. Cretaceous Research, 26, 171-179.

DOI: $10.1016 /$ j.cretres.2004.10.002

Fürsich, F.T., Singh, I.B., Joachimskic, M., Krummc, S., Schlirf, M. and Schlirf, S.: 2005, Palaeoclimate reconstructions of the Middle Jurassic of Kachchh (western India): an integrated approach based on palaeoecological, oxygen isotopic, and clay mineralogical data. Palaeogeography, Palaeoclimatology, Palaeoecology, 217, 289-309.

DOI: $10.1016 /$ j.palaeo.2004.11.026 
Hardy, R. and Tucker, M.: 1988, X-ray powder diraction of sediments. In Techniques in sedimentology (ed. Tucker, M.), 191-228.

Haq, B.U., Hardenbol, J. and Vail, P.R.: 1987, Chronology of fluctuating the sea levels since Triassic. Science, $235,1156-1167$. DOI: $10.1126 /$ science.235.4793.1156

Haywood, A.M., Valdesb, P.J. and Markwickc, P.J.: 2004, Cretaceous (Wealden) climates: a modelling perspective. Cretaceous Research, 25, 303-311. DOI: 10.1016/j.cretres.2004.01.005

Jackson, M.L.: 1975, Soil Chemical Analysis. Advanced Course. Univ. of Wisconsin, College of Agric., Dept. of Soils, Madison, Wisconsin.

Johns, W.D., Grim, R.E. and Bradley, F.: 1954, Quantitative estimation of clay minerals by diffraction methods. J. Sediment. Petrol., 24, 242-251.

Kemp Van De, P.C.: 2008, Smectite-illite-muscovite transformations, quartz dissolution and silica release in shales. Clays Clay Miner, 56, 66-81. DOI: $10.1346 / C C M N .2008 .0560106$

Khormali, F. and Abtahi, A.: 2003, Origin and distribution of clay minerals in calcareous arid and semi-arid soils of Fars Province, southern Iran. Clay Miner, 38, 511527. DOI: $10.1180 / 0009855023740112$

Khormali, F., Abtahi, A. and Owliaei, H.R.: 2005, Late Mesozoic-Cenozoic clay mineral rocks of southern Iran and their palaeoclimatic implications. Clay Miner, 40, 191-203. DOI: 10.1180/0009855054020165

Kittrick, J.A. and Hope, E.W.: 1963, A procedure for the particle size separation of soils for X-ray diffraction analysis. Soil Sci., 96, 312-325.

Larsen, G., and Chilinger, G.V.: 1983, Diagenesis in sediments and sedimentary rocks, 2 (Devel. Sed. 25B). Elsevier North Holland Inc., NY.

Li, L., Keller, G., Adatte, T. and Stinnesbeck, W.: 2000, Late Cretaceous sea-level changes in Tunisia: a multidisciplinary approach. Journal of the Geological Society, 157, 447-458.

Madhavaraju, J., Ramasamy, S., Alastair, Ruffell and Mohan, S.P.: 2002, Clay mineralogy of the Late Cretaceous and early Tertiary rocks of the Cauvery Basin (southeastern India): implications for sediment source and palaeoclimates at the K/T boundary. Cretaceous Research, 23, 153-163. DOI: $10.1006 /$ cres. 2002.0310

McKinley, J.M., Worden, R.H., and Raffell, A.H.: 2003, Smectite in sandstones: a review of the controls on occurrence and behavior during diagenesis. In: (Worden, R.H. and Morad, S., eds.) Clay Mineral Cements in Sandstones. Spec. Publs Int. Assoc. Sediment., No. 34, pp. 109-128. Blackwell Publishers, Oxford.

Mehra, O.P. and Jackson, M.L.: 1960, Iron oxide removal from soils and clays by a dithionite citrate system with sodium bicarbonate. Clays Clay Miner., 7, 317-327.

Moore, D.M., and Reynolds, R.C.: 1989, X-ray diffraction and identification and analysis of clay minerals, Oxford University Press, 332pp.

Mortazavi, M, Moussavi-Harami R., Mahboubi, A. and Nadjafi M.: 2013, Geochemistry of the Late JurassicEarly Cretaceous shales (Shurijeh formation) in the intracontinental Kopet Dagh basin, north-eastern Iran. Arabian Journal of Geosciences, 7, 5353-5366. DOI: $10.1007 / \mathrm{s} 12517-013-1081-4$
Nadeau, P.H., Wilson, M.J., McHardy, W.J., and Tait, J.M.: 1984, Interstratified clays as fundamental particles. Science, 225: 923-925. DOI: $10.1126 /$ science. 225.4665 .923

Pletsch, T., Daoudi, L., Chamley, H., Deconinck, J.F. and Charroud, M.: 1996, Palaeogeographic controls on palygorskite occurrence in Mid-Cretaceous sediments of Morocco and adjacent basins. Clay Miner., 31, 403-416. DOI: 10.1180/claymin.1996.031.3.10

Raisossadat, S.N.: 2004, The ammonite family eshayesitidae in the KD Basin, north-east Iran. Cretaceous Research. 25. 115-136. DOI: 10.1016/j.cretres.2003.10.007

Ritz, M., Vaculikova, L., Plevova, E., Matysek, D. and Malis, J.: 2012, Determination of chlorite, muscovite, albite and quartz in claystones and clay shales by infrared spectroscopy and partial least-squares regression. Acta Geodyn. Geomater., 9, 4 (168), 511520.

Roberson, H.E., and Lahann, R.W.: 1981, Smectite to illite conversion rates. Effects of solution chemistry. Clays Clay Miner., 29, 129-135.

DOI: 10.1346/CCMN.1981.0290207

Robert, A.M.M., Letouzey, J., Kavoosi, M.A., Sherkati, S., Müller, C., Vergés, J. and Aghababaei, A.: 2014, Structural evolution of the Kopeh Dagh fold-andthrust belt (NE Iran) and interactions with the South Caspian Sea Basin and Amu Darya Basin. Marine and Petroleum Geology, 57, 68-87.

DOI: $10.1016 /$ j.marpetgeo.2014.05.002

Robert, M.: 1973, The experimental transformation of mica towards smectite. Relative importance of total charge and tetrahedral substitution. Clays Clay Miner, 21(3): 167-174. DOI: 10.1346/CCMN.1973.0210305

Sanguesa, F.J., Arostegui, J. and Suarez-Ruiz, I.: 2000, Distribution and origin of clay minerals in the Lower Cretaceous of the Alava Block (Basque-Cantabrian Basin, Spain). Clay Miner., 35, 393-410. DOI: $10.1180 / 000985500546864$

Schieber, J.: 1986, Stratigraphic control of rare-earth pattern types in mid-Proterozoic sediments of the Belt Super Group, Montana, U.S.A.: implications for basin analysis. Chemical Geology, 54, 135-148.

DOI: $10.1016 / 0009-2541(86) 90077-X$

Seyed-Emami, K., and Alavi Naini, M.: 1990, Bajocian Stage in Iran. Memorie Descrittive della Carta Geologica d'Italia, 40, 215-222.

Seyed-Emami, K., Schairer, G. and Behroozi, A.: 1996, Ammoniten aus dem Oberen Bajoc (Mittlerer Jura) des SE-Koppeh Dagh und SE -Alborz (NE-Iran). Mitteilungen der Bayerischen Staatssammlung fur Palaeontologie und Historische Geologie, 36, 87-106.

Shoval, S.: 2004, Clay sedimentation along the southeastern Neo-Tethys margin during the oceanic convergence stage. Applied Clay Science, 24, 287-298.

DOI: 10.1016/j.clay.2003.08.010

Weaver, C.E.: 1959, The clay petrology in sediments. Clays Clay Miner., 6: 154-187.

Worden, R.H., and Burely, S.D.: 2003, Sandstone Diagenesis, Blackwell Publishers, 644pp.

Zaaboub, N., Abdeljaouad, S. and López-Galindo, A.: 2005, Origin of fibrous clays in Tunisian Paleogene continental deposits. Journal of African Earth Science, 43, 491-504. DOI: 10.1016/j.jafrearsci.2005.08.013

Zahedi, M.: 1976, Explanatory text of the Esfahan quadrangle map 1:250000. Geological Survey of Iran. 